\title{
PENGARUH PENERAPAN MODEL PEMBELAJARAN KOOPERATIF \\ INFORMAL TIPE FORMULATE SHARE LISTENING CREATE TERHADAP PEMAHAMAN KONSEP MATEMATIS SISWA KELAS VII.2 MTsN 12 PESISIR SELATAN
}

\author{
Siska Elmiwarni, Yulia Haryono, Radhya Yusri \\ Program Studi Pendidikan Matematika STKIP PGRI Sumatera Barat \\ siskaelmiwarni@gmail.com
}

\begin{abstract}
This research is motivated by the low ability of students to understand mathematical concepts and students are not used to discussing. The research objective was to determine how the effect of the application of the formulate share listening create informal cooperative learning model on the understanding of the mathematical concepts of class VII.2 students of MTsN 12 Pesisir Selatan.This research is a descriptive quantitative research based on one shoot case study. The population in this study were students of class VII MTsN 12 Pesisir Selatan which consisted of 5 classes. The sampling technique was taken using purposive sampling, so that class VII.2 MTsN 12 Pesisir Selatan was chosen as the sempel class. The research instrument was the final test in the form of an essay and the reliability of $r_{11}=0,70$. Where based on data analysis the value of the trial class.Based on the calculation results, it was found that the percentage of learning outcomes with the conceptual understanding indicator obtained by students while using the formulate share listening create informal cooperative learning model was quite good. $61 \%$. So it can be concluded that by applying the informal cooperative learning model type formulate share listening create to the students' ability to understand mathematical concepts class VII.2 MTsN 12 Pesisir Selatan is quite good.
\end{abstract}

\section{Keywords: Cooperatif Learning, Formulate Share Listening Create, Mathematical Concepts}

\section{PENDAHULUAN}

Matematika merupakan salah satu pelajaran yang menunjang ilmu pengetahuan.

Dikatakan bahwa proses
pembelajaran matematika dalam
implementasi kurikulum 2013 terdiri
dari pengalaman pokok belajar yaitu
menanya, mengamati, mengumpulkan
informasi, mengasosiasikan, dan

mengkomunikasikan (Depdiknas, 2001)

Dikatakan bahwa pemahaman konsep merupakan dasar yang sangat penting dalam menyelesaikan masalah, dikarenakan pemahaman konsep merupakan hal mendasar dalam menyelesaikan masalah. Jadi untuk memahami konsep matematika siswa hendaknya memulai dengan 
memahami konsep prasyarat dari materi tersebut, sehingga setiap permasalahan akan mampu diselesaikan. Karena untuk mengaji informasi yang didapat siswa hendaknya memahami konsep terlebih dahulu. (Yusri, 2017).

Berdasarkan wawancara dan observasi dengan guru mata pelajaran matematika kelas VII MTsN 12 Pesisir Selatan, guru mengatakan bahwa keaktifan siswa ketika proses pembelajaran masih kurang dan siswa lebih suka menerima materi dari guru. Kebanyakan siswa mencontek dan hanya menyalin punya temannya tanpa bertanya kembali, hal ini disebakan oleh tidak terbiasanya siswa menemukan konsep sendiri sehingga tidak paham cara penerapan konsep tersebut. Proses pembelajran guru tidak melakukan diskusi karena tidak semua siswa ikut berpartisipasi dan akan memakan waktu sedangkan dalam proses pembelajara dibutuhkan banyak penjelasan. Dari wawancara siswa mereka mengatakan matematika itu pelajaran yang susah. Rendahnya hasil belajar siswa disebabkan kurangnya kemampuan siswa memahami konsep dari materi yang diajarkan..

\begin{abstract}
Pembelajaran kooperatif informal mempunyai beberapa prosedur, prosedur ini akan membantu guru dalam merencanakan penyampaian pembelajaran dengan tetap mempertahankan keterlibatan siswa secara intelektual, sehingga Pembelajaran kooperatif informal efektif menjadikan siswa aktif dalam memahami pembelajaran. (Johnson, 2010)

Tujuan dari penelitian ini adalah untuk mengetahui bagaimana pemahaman konsep matematis siswa saat menggunaakan model pembelajaran kooperatif informal tipe formulate share listening create (FSLC) kelas VII. 2 MTsN 12 Pesisir Selatan.
\end{abstract}

\section{METODE PENELITIAN}

Penelitian yang dilakukan ini merupakan penelitian deskriptif kuantitatif dengan memakai desain penelitian yaitu one shoot case study. Penelitian ini melibatkan sekelombok objek yang diberikan sebuah perlakuan (X) dan ter akhir (O). penelitian ini bermaksud untuk melihat kemampuan pemahaman konsep siswa mengunakan model pembelajaran kooperatif informal tipe 
FSLC pada kelas VII.2 MTsN 12 Pesisir Selatan.

Variabel bebas dari penelitian ini yaitu model pembelajaraan kooperatif informal tipe FLSC dan variabel terikatnya yaitu pemahaman konsep matematika siswa kelas VII.2 MTsN 12 pesisir selatan.

Instrumen yang dipakai pada penelitian ini ialah one shoot case study yang berbentuk essay. Uji coba tes dilakukan terlebih dahulu di MTsN 12 balai selasa sebelum melakukan tes akhir. Hasil dari nilai uji coba tes dianalisis untuk mendapatkan tingkat kesukaran dan daya pembeda yang berpedoman pada serta reliabilitas soal yang berpedoman pada Arikunto. Berdasarkan analisis butir soal uji coba setelah dilakukan perhitungan diperoleh kriteria tingkat kesukaran soal berada pada rentang $0,30-1,00$ yang menunjukkan tingkat kesukaran pada no soal 2, 3, dan 4 dengan kriteria mudah, dan soal no $1,5 \mathrm{a}$, dan 5b dengan kriteria sedang. Hasil perhitungan diperoleh di peroleh $\mathrm{r}_{11}=$ 0,70 sedangkan $r_{\text {tabel }}=0,344$ berarti soal reliable karena $r_{11}>r_{\text {tabel }}$ jadi instrumen dapat dipercaya untuk menggumpulkan data (Arikunto, 2010).

\section{HASIL DAN PEMBAHASAN}

Menurut tindakan yang dilaksanakan pada kelas eksperimen, didapat data Skor hasil belajar siswa dengan indikator pemahaman konsep dengan perhitungan nilai rata-rata siswa $(\bar{X})$, nilai simpangan baku siswa $(S)$, skor tertinggi nilai siswa ( $X_{\text {maks }}$ ) dan skor terendah nilai siswa $\left(X_{\min }\right)$. Dapat dilihat hasil perhitungan berikut:

Tabel 1 Hasil Perhitungan Nilai Tes Akhir Pemahama Konsep Siswa

\begin{tabular}{ll}
\hline $\begin{array}{l}\text { Kelas } \\
\text { Diberi } \\
\text { Perlakuan }\end{array}$ & Hasil \\
\hline $\bar{X}$ & 64,78 \\
$S$ & 29,54 \\
$X_{\text {maks }}$ & 100 \\
$X_{\min }$ & 4,17 \\
\hline
\end{tabular}

Berdasarkan tes akhir yang dilaksanakan 16 dari 31 siswa tuntas dalam proses pembelajaran yang dilaksanakan karena telah memenuhi Kritera Nilai Ketuntasan Minimum (KKM) yang telah ditetapkan MTsN 12 Pesisir Selatan yaitu 75 dengan nilai terendah 4,17 , tertinggi 100 
sehingga terdapat simpangan bakunya 29,54 dan rata-rata 64,78 .

Proses pembelajaran yang dilakukan pada kelas eksperimen diawal Pengorganisasian awal guru mempersiapkan siswa untuk belajar, membagi siswa kedalam kelompok berpasangan , menyampaikan tujuan pembelajaran. Pada proses penyampaian pembelajaran guru hanya menyampaikan materi secara garis besar. Pada proses diskusi berpasangan siswa duduk dengan pasangannya yang telah ditunjuk pada saat awal, kemudian siswa akan diberikan tugas, pada tahap ini akan terjadi proses formulate yaitu siswa memikirkan jawaban masing masing kemudian share yaitu siswa membagi jawabannya dengan teman sekelompoknya setelah itu pasangan kelompoknya akan mendengarkan jawaban yang diberikan oleh pasangan kelompoknya. Kemudian create kelompok berpasangan membuat jawaban baru dari ide ide terbaik bersama. pada proses diskusi terfokus beberapa kelompok akan maju dan menjelaskan hasil diskusi mereka sementara kelompok lain mendengarkan penjelasan dari kelompok yang menjelaskan hasil diskusi mereka.

Berikut contoh lembar individu

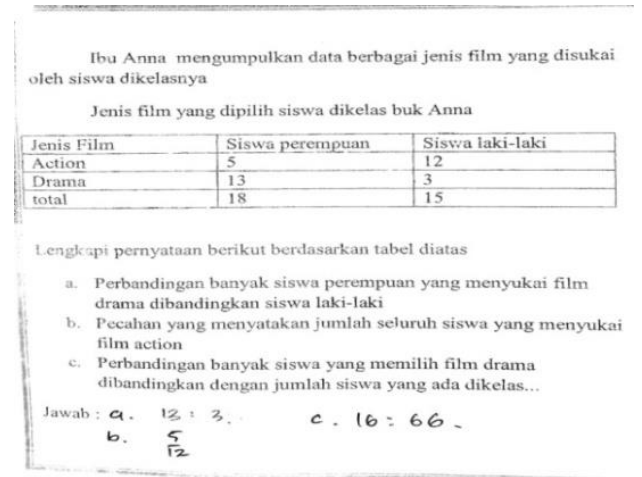

Gambar 1: Lembar Individu Siswa

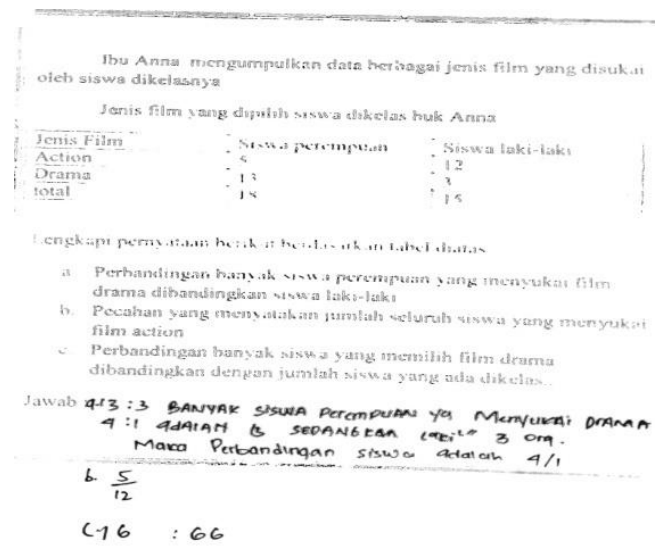

Gambar 2: Lembar Individu Siswa 2

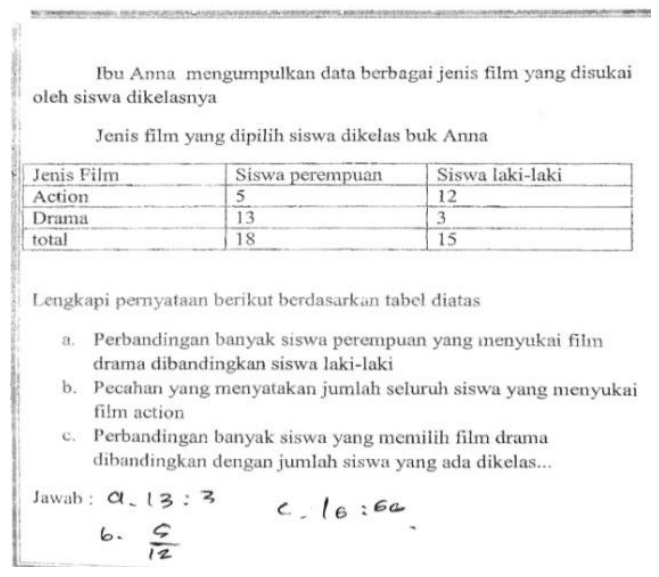

Gambar 3: Jawaban Lembar Pasangan 
Berdasarkan lembar jawaban yang dibuat siswa dalam kelompok berasangandan individu pada gambar 1, 2, 3, siswa sudah paham dengan materi tersebut, siswa telah paham mengerjakan tentang perbandingan skala tetapi siswa belum dapat berdiskusi dengan temannya dengan baik, terliha bahwa hanya salah satu siswa yang menyalin dari lembar individunya ke lembar diskusi.

$$
\text { Pertemuan kedua tahap }
$$
pelaksanaannya sama dengan tahap pelaksanaan pertemuan pertama. Pada pertemuan kedua ini siswa sudah menunjukkan bahwa pemahaman konsep ketika mengaplikasikan konsep atau algoritma ketika pemecahan masalah dan saat pertemuan kedua ini juga dapat dilihat pada lembar individu dan kelompok bahwa diskusi dan FSLC telah berjalan dengan baik serta berdikusi dengan teman sebangkunya juga berjalan dengan baik. Namun dalam proses belajar mengajar pada pertemuan dua ini tidak berjalan lancar karena jadwal pembelajaran terpotong karena siswa harus berlatih upacara untuk hari senin.

Pada soal berasangan pertemuan ketiga siswa sudah sesuai dengan konsep dalam mengaplikasikan konsep dan pada pertemuan ketiga ini bahwa FSLC telah berjalan dengan baik dan siswa sudah mampu berdiskusi dengan teman sebangkunya.

Tes akhir diberikan setelah pokok bahasan perbandingan selesai dipelajari oleh siswa.

Berikut hasil test akhir siswa dengan indikator pemahaman konsep

a) Mengklasifikasikan Objek Berdasarkan Sifat Sesuai Konsep Dalam Bentuk Representasi Matematika.. Indikator pemahaman konsep matematika yang kedua terdapat pada butir soal posttest nomor 3 . Siswa diminta untuk mengklasifikasi obejek berdasarkan sifat menurut konsepnya. Berikut gambar jawaban salah satu siswa.

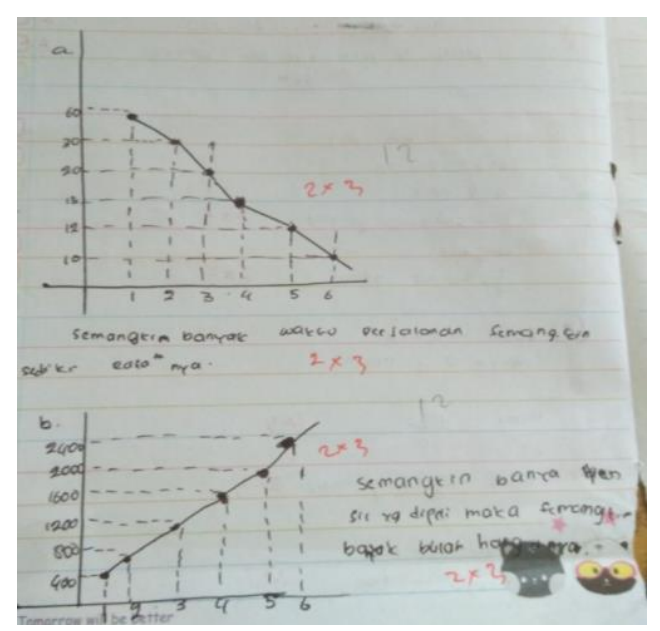

Gambar 4 . Lembar Jawaban Siswa 
Berdasarkan jawaban siswa pada Gambar 4, terlihat bahwa siswa sudah mampu dalam menentukan jenis grafik dari tabel dan menggambarkan grafik. Terlihat sudah bisa menginterpretasikan soal dan menuliskan jawaban dengan benar. Sehingga dapat ditarik kesimpulan bahwa pemahaman konsep matematis siswa sudah cukup baik.

b) Menyatakan Ulang Sebuah Konsep Serta Mengaplikasikan Konsep Kedalam Pemecahan Masalah Indikator Pemahaman konsep matematika yang dua dapat dilihat pada butir soal posttest nomor 1 dan 2 . Salah satu soal dengan indikator mengaplikasikan kosep ke pemecahan masalah terdapat di soal nomor 1 yaitu menyelesaikan perbandingan senilai

Berikut salah satu jawaban siswa terlihat pada gambar berikut ini.

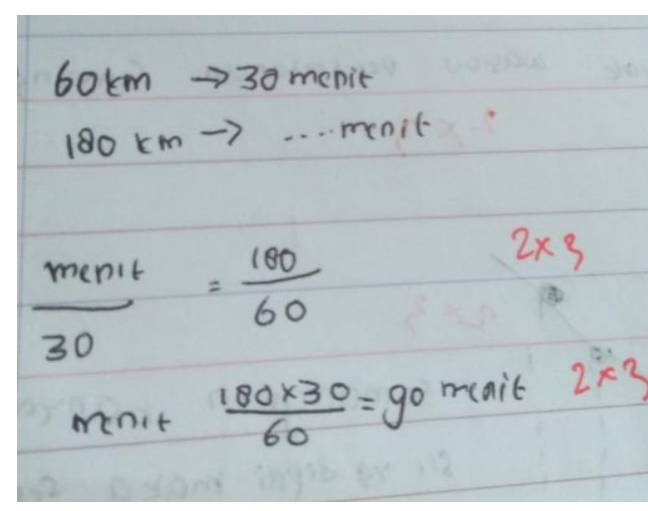

Gambar 5. Lembar jawaban
Jawaban siswa pada Gambar menunjukkan bahwa siswa memahami masalah yang diberikan guru karena bisa mengerjakan dan menyelesaikan soal dengan benar. Siswa terlihat telah mampu menjelaskan dan menulis jawaban dengan benar.

Berdasarkan tes akhir deskripsi dan analisis data terlihat bahwa rata-rata terlihat bahwa ratarata nilai tes akhir pada kelas VII.2 adalah 64,78 dengan nilai terendah 4,17 dannilai tertinggi 100 .

Dilihat dari kriteria ketuntasan Minimal (KKM) pada kelas VII.2 sebanyak 16 orang . Jadi, berdasarkan data yang diperoleh tampak bahwa menggunakan model pembelajaran kooperatif informal tipe $F S L C$ hasil belajar siswa dengan indikator pemahaman konsep. Karena dengan Strategi ini bisa memberikan kesempatan kepada peserta didik untuk mengembangkan kemampuan yang mereka miliki. Sehingga mereka aktif selama pembelajaran berlangsung. Kelebihan dari model kooperatif informal tipe FSLC ini siswa dapat berdiskusi bersama teman sebangkunya serta tidak ada yang merasa malu untuk menanyampaikan 
hasil diskusi berpasangannya. Selama ini banyak siswa yang tidak mau maju kedepan untuk menyampaikan hasil diskusinhya karena merasa malu akan ditertawakan atau disalahkan oleh teman-temannya.

Penelitian ini sebelumnya telah dilakukan oleh (Lia, 2018) dengan judul: "Pengaruh Penerapan Model Pembelajaran Kooperatif Informal Tipe Formulate-ShareListen-Create (FLSC) Terhadap Pemahaman Konsep Matematis Siswa Kelas XI IPA SMAN 15 Padang". dalam proses pembelajarannya dibagi pada empat tahap yaitu perorganisasian awal, penyampaian pembelajaran, diskusi berpasangan, dan diskusi terfokus. Pengorganisasian awal guru mempersiapkan siswa untuk belajar, membagi siswa kedalam kelompok berpasangan , menyampaikan tujuan pembelajaran. Pada proses penyampaian pembelajaran guru hanya menyampaikan materi secara garis besar. Pada prose diskusi berpasangan siswa duduk dengan pasangannya yang telah ditunjuk pada saat awal, kemudian siswa akan diberikan tugas, pada tahap ini akan terjadi proses formulate yaitu siswa memikirkan jawaban masing masing kemudian share yaitu siswa membagi jawabannya dengan teman sekelompoknya setelah itu pasangan kelompoknya akan mendengarkan jawaban yang diberikan oleh pasangan kelompoknya. Kemudian create kelompok berpasangan memperoleh jawaban baru berdasarkan gabuangan ide-ide terbaik. pada proses diskusi terfokus beberapa kelompok akan maju dan menjelaskan hasil diskusi mereka sementara kelompok lain mendengarkan penjelasan dari kelompok yang menjelaskan hasil diskusi mereka. Perbedaan penelitian sebelumnya penelitian eksperimen dengan rancangan rendom terhadap subjek dengan teknik pengambilan sempel acak siswa kelas XI IPA SMAN 15 Padang, sedangkan penelitan ini merupakan penelitian deskriptif kuantitatif dengan disain penelitian penelitian one shoot case study dan menggunakan teknik pengambilan sampel yaitu menggunakan purposive sampling, sehingga terpilih kelas VII.2 MTsN 12 Pesisir Selatan. 


\section{KESIMPULAN}

Berdasarkan hasil perhitungan diperoleh bahwa persentase Hasil belajar dengan indikator pemahaman konsep yang diperoleh siswa selama menggunakan model pembelajaran kooperatif informal tipe FSLC cukup berhasil. Dengan perolehan data siswa yang mendapat nilai diatas KKM sebanyak 51,61\%. Sehingga dapat disimpulkan bahwa dengan melakukan model pembelajaran kooperatif informal tipe FSLC terhadap kemapuan pemahaman konsep matematis siswa kelas VII.2 MTsN 12 Pesisir Selatan cukup baik.

\section{DAFTAR PUSTAKA}

Arikunto, S. (2010). Prosedur Penelitian Suatu Pendekatan Praktik (edisi revisi). Rineka Cipta.

Depdiknas. (2001). Penyusunan Butir Soal dan Instrumen Penilaian. Diknasmen.

Johnson, johnson D. W. R. . \& E. J. holubece. (2010). coolaborattif learning (terjemahan). nusa media.

Lia, A. (2018). Pengaruh Penerapan Model Pembelajaran Kooperatif Informal Tipe Formulate-ShareListen-Create (FSLC) Terhadap Pemahaman Konsep Matematis Siswa Kelas XI IPA SMAN 15 Padang. STIKP PGRI Sumatera Barat.
Yusri, R. (2017). Pengaruh Pendekatan Problem Centered Learning Terhadap Kemampuan Pemahaman Konsep Dan Pemecahan Masalah Matematis Siswa Kelas X Sma Negeri Kabupaten Solok. Jurnal LEMMA, 3(1). https://doi.org/10.22202/j1.2017. v3i1.1389 